\title{
Revitalizing Environment Order against Spatial Outside in Cikapayang River Park Area
}

\author{
Theresia Pynkyawati ${ }^{1}$, Friska Hera Yulinda ${ }^{1}$, Fajar Nurdarajat ${ }^{1}$, Yuda Septiyagi ${ }^{1}$ \\ ${ }^{1}$ Department of Architecture/ Faculty of Civil Engineering and Planning, ITENAS, Indonesia. \\ thres@itenas.ac.id
}

\begin{abstract}
Cikapayang River Park's pedestrian area that's less organized from the ecological and environmental side. New Cikapayang River Park aims to provide comfortable public space while utilizing the river as a mutually interconnected supporting component. Outer space Environmental order includes environmental order against external order, Merdeka street corridor, which's restricted by the Cikapayang river, Bandung City Hall, Cikapayang River, and Merdeka street, also Cikapayang river purification. Previously, Cikapayang River Park's a single function as a sidewalk. After revitalization, it has an additional function as better public open spaces. Also, the Cikapayang river restoration became the basis of this research. The descriptive-analytical method used as a methodology through a direct survey to Cikapayang River Park from changing environmental order into public open space, then associating survey results conditions, before and after revitalizing to literature as the basis of theories and river purification. Analysis results showed the impact of revitalization on Cikapayang River Park's creating positive outdoor space so that it can accommodate the people's activities.
\end{abstract}

(C) 2020 IJBESR. All rights reserved.

Keywords: revitalization, environmental order, outer spatial, restoration, public open space

\section{Introduction}

The public open space, in general, is an open space that is made up of green open spaces and non-green open spaces. Open space is an environmentally sound component and has a meaning as a landscape, where there're hardscape and soft-scape elements. The public open space serves as a recreational place in the urban sphere with attention to functions and components of tread in open spaces related to functions and roles. It can be known the influence of public open spaces on the surrounding area.

Cikapayang River Park is located in Bandung City Hall, precisely on Merdeka Street, Babakan Ciamis, Bandung, which was inaugurated on 31 December 2015 and had a river as a supporting component makes this open space alive and useful to the surrounding community. Rivers have many strategic roles, such as water supply, tackling floods, improving microclimate, ecosystem health, and green lines. Such conditions are the purpose of restoration of Cikapayang River, where restoration is restoring to its original state [1].

Rivers become supporting components as an ecosystem interconnected with the surrounding community. Cikapayang River Park has approximately $3630 \mathrm{~m} 2$ with $400 \mathrm{~m}$ pedestrian length from Aceh street to BI Building (Bank of Indonesia). CIkapayang River Park has a site orientation: Aceh street in the north, Banjarsari Elementary School on the East, Bank of Indonesia in the south, and Bandung City Hall Park on the west. This infrastructure project costs 5.2 billion rupiahs and is completed within 45 days of employment. 


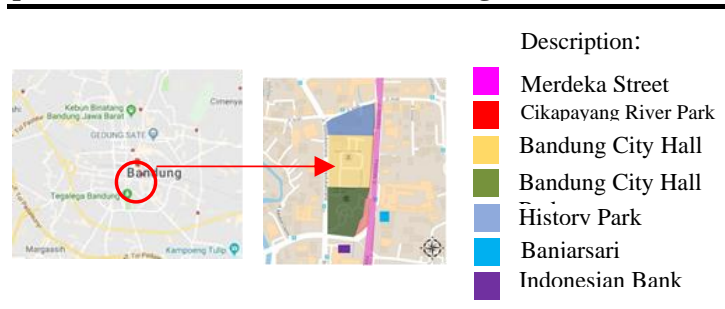

Figure 1: Location of Cikapayang River Park Source: (Google, edited by author, 2019)

According to Hariato Kunto in Wajah Bandoeng Tempo Doeloe, 1984, at first, the Cikapayang river was the idea of the reign of $\mathrm{Rd}$. Martanagara. Cikapayang itself is a channel line; hereinafter the channel is better known as the Cikapayang River. At that time, through the channels excavated by the population, water from the Cikapayang River is lined up to 4 gardens, namely Izgerman Park, Pieter Park (City Hall Park) as in Figure 2, Molukken Park (Maluku Park), and Insulude Park (Taman Lalu Lintas).

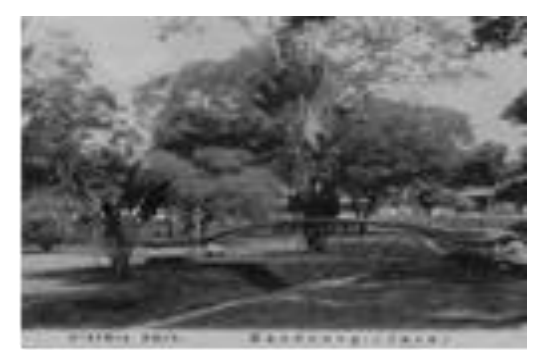

Figure 2: Pieter Park in 1885 (City Hall) Source: (Hariato Kunto, 1984)

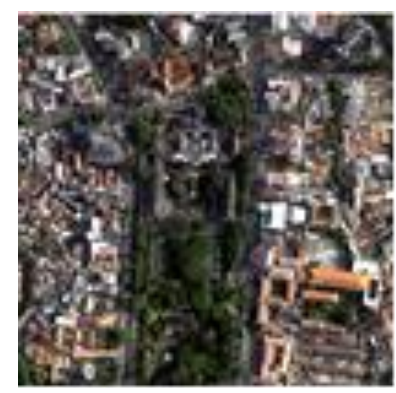

Figure 3: Aerial Photo of Cikapayang River Park Before Revitalized

Source: (Bandung Spatial Planning Office, edited by author, 2019)

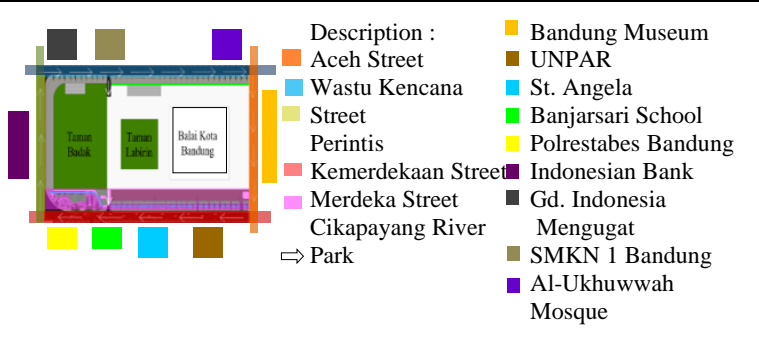

Figure 4: Keyplan

Source: (Author, 2019)

Revitalization is an effort to increase the value of land or region through rebuilding in an area that can improve the function of the previous region. The area is a region that has the primary function of protection or cultivation [5]. Before revitalization, the state of Cikapayang River Park has a less laid-out condition from the environmental and ecological side of the river flow.

The revitalization effort of Cikapayang River aims to increase the value of previous area functions through the reordering process. This revitalization seeks to make a comfortable public open space and increase public awareness of the importance of the river.

\section{Material and Methods}

Environmental order of liquid art and science regarding the preparation of the use of land portion. Site designers design based on details with the selection and analysis of site, shape, land use, vehicle arrangement, pedestrian circulation, development of visual and material forms, and rearranging the shape or form of start by designing. The elements that are the basis of the environmental order, in which the planning site takes four intertwined elements are architectural elements (architecture), civil engineering, and Elements of Landscape architecture and planning [6]. 


\subsection{Public Open Space Order}

Effectively general public open space was consists of green open space and non-green space. Open space is an environment based component, it can describe as a landscape, which there are hardscape and softscape elements, parks or recreational spaces within the urban sphere [7].

Table 1: Functions and benefits of green open space

\begin{tabular}{|c|c|c|}
\hline No & Figure & Description \\
\hline 1 & 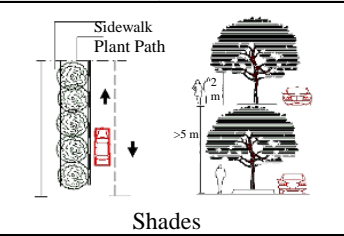 & $\begin{array}{l}\text { A branch of the tree must be } \\
2 \text { meters above the ground, } \\
\text { the mass of dense leaves and } \\
\text { planted in a lined. For } \\
\text { example: Kiara Payung, } \\
\text { Flowers. }\end{array}$ \\
\hline 2 & Air Pollution absorber & $\begin{array}{l}\text { Consisting of trees, shrubs. } \\
\text { Spacing of tightly planted } \\
\text { and has solid leaf mass. } \\
\text { For example, Ketapang } \\
\text { Kencana, and Acacia }\end{array}$ \\
\hline 3 & $\begin{array}{lll}\text { Sight planting space } \\
\text { Shrubs and bushes }\end{array}$ & $\begin{array}{l}\text { It consists of trees, } \\
\text { shrubs/bushes, forming } \\
\text { masses and having a solid } \\
\text { leaf mass. For examples: } \\
\text { Kiara payung, and hibiscus }\end{array}$ \\
\hline 4 & 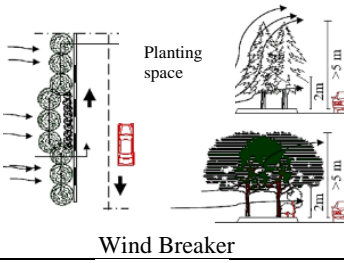 & $\begin{array}{l}\text { It is a high crop, shrubs or } \\
\text { bush, solid leaves, and has a } \\
\text { space less than } 3 \text { meters. For } \\
\text { example Mahogany tree, } \\
\text { Kiara Payung. }\end{array}$ \\
\hline 5 & Disibility & $\begin{array}{l}\text { In the form of tall crops, the } \\
\text { shrubs have solid leaf } \\
\text { masses and are planting } \\
\text { lined up or forming a mass. } \\
\text { For example bamboo tree, } \\
\text { cypress, hibiscus }\end{array}$ \\
\hline
\end{tabular}

Source: (Ministry of Home Affairs, 1988)

One of the public open space order is Island Road and Median road. Park Island Road is a green open space that is formed by geometrical roads such as at crossing three or roundabout roads. The median is a dividing line dividing the road into two or more lanes [8]. Roads and median islands that form gardens or green open spaces can be seen in Table 2 .

Table 2: Road's Green Area and Road Median

\begin{tabular}{|c|c|}
\hline Function & Benefit \\
\hline $\begin{array}{l}\text { - As protection area of } \\
\text { ecosystem function and life } \\
\text { buffer; } \\
\text { - As facilities to create } \\
\text { cleanliness, health, harmony } \\
\text { and environmental life; } \\
\text { - As recreation facilities; } \\
\text { - As an urban environment } \\
\text { safeguard against various kinds } \\
\text { of pollution in both land, water } \\
\text { and air; } \\
\text { - As a means of research and } \\
\text { education as well as counseling } \\
\text { for the community to form } \\
\text { awareness of environment. }\end{array}$ & $\begin{array}{l}\text { - Provide freshness, comfort } \\
\text { and beauty of sight } \\
\text { - Provide a clean and healthy } \\
\text { environment for the } \\
\text { townspeople; } \\
\text { - Produce the production of } \\
\text { wood, leaves, flowers and } \\
\text { fruit. }\end{array}$ \\
\hline
\end{tabular}

Source: (Ministry of Public Works, 2008)

\subsubsection{Outer Space Order}

The relationship between mass and outer space in architecture can be assessed and gained in its existence on several different scales. At each level, you should pay attention not only to the shape of a building but also its impact on the surrounding space. At the scale of the city, we should pay attention to whether the role of a building to pass the existing character of a place, forming a background for other buildings [9]. The public open space, as part of the site element, can be composed of a mass of buildings and vegetation. Both of them in individually or in parts of groups also become elements of the outer space forming. On the scale of a building site, a building has various strategies to connect the shape of a building to the surrounding space, as in Table 3.

Table 3: Outdoor space relations

\begin{tabular}{|c|c|l|}
\hline No & \multicolumn{1}{|c|}{ Figure } & \multicolumn{1}{c|}{ Description } \\
\hline 1. & $\begin{array}{l}\text { Form a wall along the } \\
\text { edges of its site and begins } \\
\text { defining a positive outdoor } \\
\text { space }\end{array}$ \\
\hline 2. & & $\begin{array}{l}\text { Stand as a special object } \\
\text { and dominate through its } \\
\text { topographical form and } \\
\text { placement-an extrovert } \\
\text { scheme }\end{array}$ \\
\hline
\end{tabular}

Source: (D.K. Ching, 2007) 


\subsection{User Circulation}

Accessibility is the most important thing to access and connect the primary elements of space on land, parking, entrance, facilities, and buildings. The route of accessibility to access facilities, including site entrance, parking area, drop off zone, waiting area, rest area, and pedestrian [10], is shown in Figure 5.

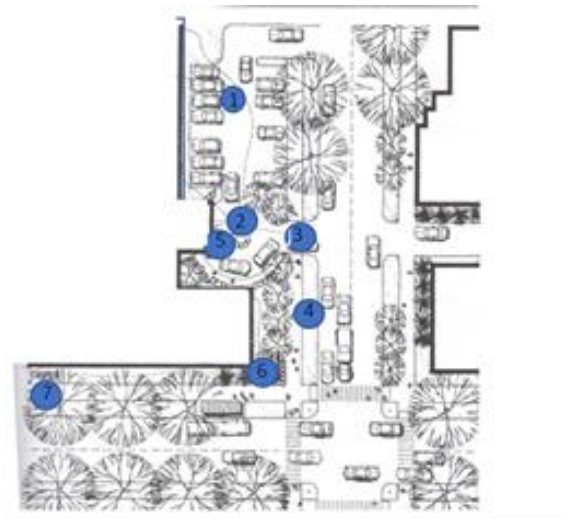

Figure 5: Accessibility Routes Source: (W. Harris and T. Dines, 1998)

Circulation is an individual move from one social class to another, both vertically and horizontally [11]. Circulation is the kinetics of movement, a study of the nature of the action. Various types of trajectory, according to them, are outlined in Table 4.

Table 4: Various Type of Trajectory

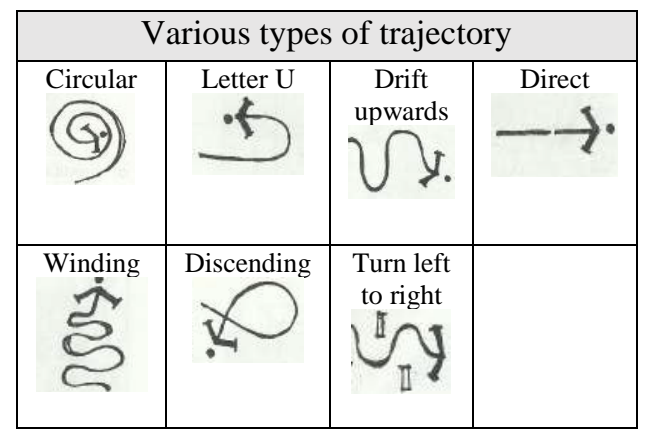

Source: (Rustam and Hardi, 2004)

The biggest presentation of accidents caused by difference in ladder level is not equal (Antrede whose size is different), stairs with open rise is not recommended to be used in outdoor. Optrade should be designed securely to accommodate the user as in Figure 6.

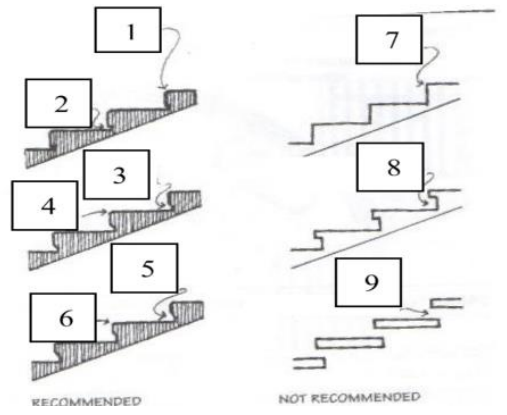

Description :

1. Edges should be chamfered

2. Shadow line should be kept to a minimum (i.e. $12 \mathrm{~mm}$ maximum)

3. 45 degree bevel

4. Chamfered edges

5. 60 degree bevel

6. Chamferd edges

7. Square nosings catch toes of shoes, braces,etc.

8. Recesses catch toes of shoes, braces, etc

9. Open risers catch toes od shoes, braces, etc

Figure 6: Outer Space Staircase Types Source: (W. Harris and T. Dines, 1998)

\subsection{Environmental Order of Site Components \\ 2.3.1 Hardscape Components}

The element of hard elements are artificial material elements or another vegetation element intended are forming garden objects, consisting of buildings, gazebos, garden chairs, fish ponds, fences, pergola, fountains, garden lamps, rocks, wood, and others.

Hard materials can be divided into 5 (five) large groups, namely:

- Natural Material (organic materials) that is wood

- Natural hard materials from inorganic materials used in their natural state are rocks, sand, and bricks

- Hard material made from metal (inorganic materials used in highly modified state) namely aluminum, iron, bronze, copper and steel artificial hard material or synthetic material that is plastic or fiberglass 
- Hard Material Artificial composite materials such as concrete and plywood [10].

\subsubsection{Softscape Components}

Softscape is a term used for material elements derived from nature. The valuable element is a dominant element, consisting of plants or trees and water. Plants not only contain aesthetic value, but to improve the quality of the environment. Types of plants are reviewed from the mass of the leaves include:

- Deciduous plants, plants that are abort leaves

- Evergreen conifers, the greenery that all year round

- Broadleaf evergreens, a plant that looks like deciduous plants but does not abort the leaves [12].

\subsection{River Water Purification}

The river has a huge role in the development of human civilization by providing fertile areas that are generally located in river valleys and water resources as an essential source of life for humanity. Similarly, the river gives itself a means of transport to increase mobility and communication between humans that mostly rainwater that drops to the ground, flows to lower places, and is experiencing various resistance due to massive force [13].

Things to be prepared in the planning of river water treatment tools include:

\section{Construction Tools}

- body coagulation, flocculation and sedimentation, hereinafter referred to as first body

- The filtering tub, hereinafter called the second.

2. Processing process

- Raw water into the appliance through PVC pipe in the first body,

- At the same time it is necessary to also solution alum and chlorine solution.
- After a scouring with a solution of alum and water chlorine flowing through gravel stones contained in PVC pipes, with these pebbles the flow of water will be winding up and become slow [14].

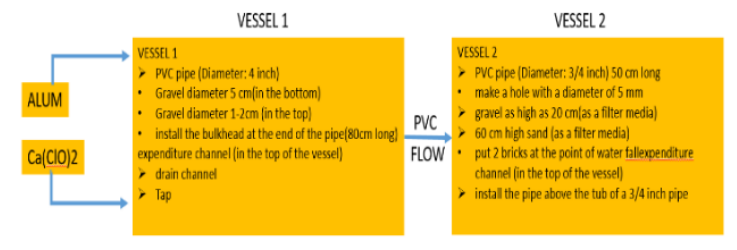

Figure 7: Water Purification Scheme Source: (Asmadi and Kasjono, 2011)

\section{Results and Discussions}

\subsection{Analysis of the environmental order to the Function of Outer Space}

The site's design for the function of the outer space is divided into two orders, namely the public open space order and the outdoor space order. The public open space of Cikapayang River Park is a green open space with an environmental perspective.

\subsubsection{Public Open Space Order}

Parks have functions and benefits that can be reviewed based on green area conditions and road medians. The green area and road median provisions have functioned as a shade, absorbing air pollution, silencer noise, windbreakers, and barrier of view [8]. One type of shade plant in this park is Ketapang Kencana, which is located in the park's pedestrian area used for activities carried out around the park's pedestrian area.

Figure 8 shows the plant order as a shade in pattern 1. And comply with the criteria [8], because it has been planted in rows with a median branching $2 \mathrm{~m}$ above the ground. As for pattern two shown in Figure 9, it does not comply with the criteria [8] because the sidewalk is directly related to the road, and there is no barrier between the sidewalk and the street. 

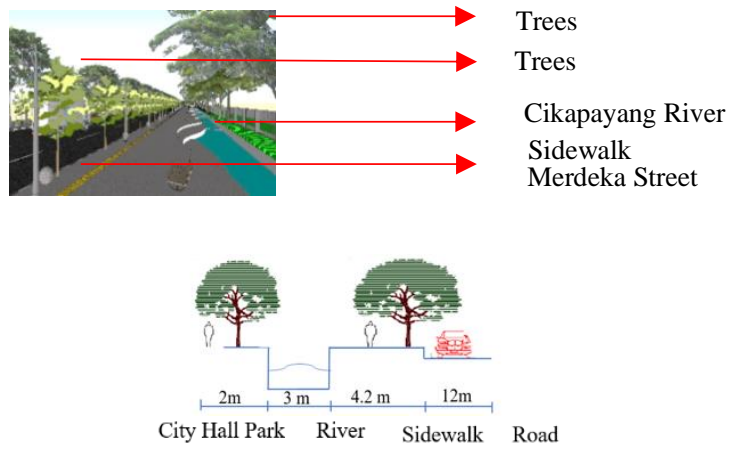

Figure 8: Shade Tree Pattern (Pattern 1)

Source: (Author, 2020)

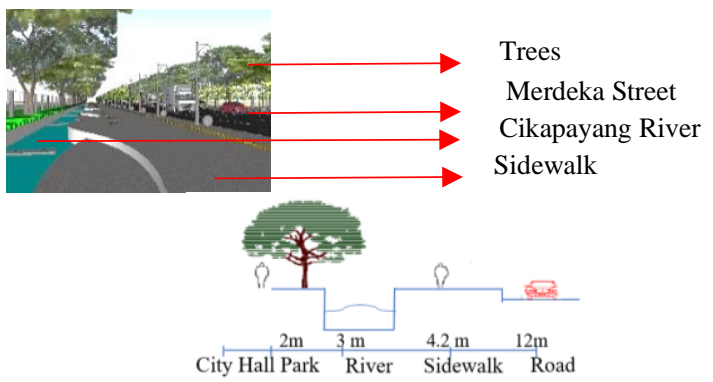

Figure 9: Shade Tree Pattern (Pattern 2)

Source: (Author, 2020)

The function of trees in the parking area is absorbers of $\mathrm{CO} 2$ pollution coming from vehicle fumes on Merdeka Street, as shown in figure 10. In addition to tree species, shrubs species also function as air pollution absorbent plants, to create an environment with better air quality well. Various types of trees, including shrubs and various types of trees, function as $\mathrm{CO} 2$ absorbers [8] from vehicle fumes on Merdeka Street.

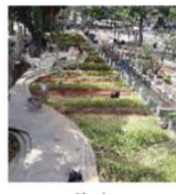

Shrubs

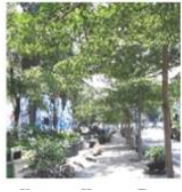

Ketapang Kencana

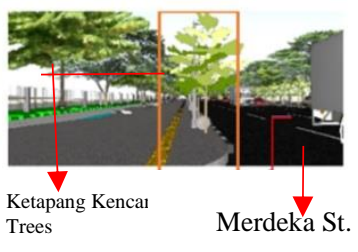

Source: (Author, 2020)
Figure 10: Plants as Absorbers of Air Pollution $\left(\mathrm{CO}_{2}\right)$

Bamboo trees are the barrier of view plants found in the Cikapayang River Park and have a

density of fewer than $3 \mathrm{~m}$, which are planted to form a period, and found shrubs that are less than $2 \mathrm{~m}$, which can be seen in Figure 11. The barrier of view plants has criteria with the time of dense leaves, planted in rows, or forming a period, the two types of view-limiting plants found in this [8] only bamboo.

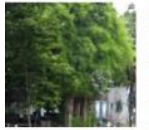

Bamboo

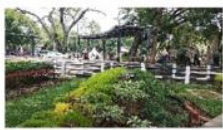

Shrubs

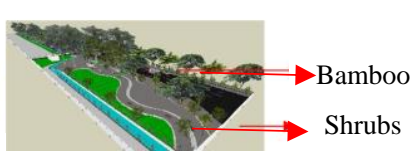

Figure 11: Tree as Barrier of View Source: (Author, 2020)

\subsubsection{Outer Space Order}

Cikapayang River Park and City Hall Park are boundaries by a barrier consisting of fences and shrubs, as shown in Figure 12. This barrier functions as a separator between Cikapayang River Park and City Hall Park; besides that, the guardrail serves to create an outdoor space that was previously a negative outer space, becomes positive outer space [9].

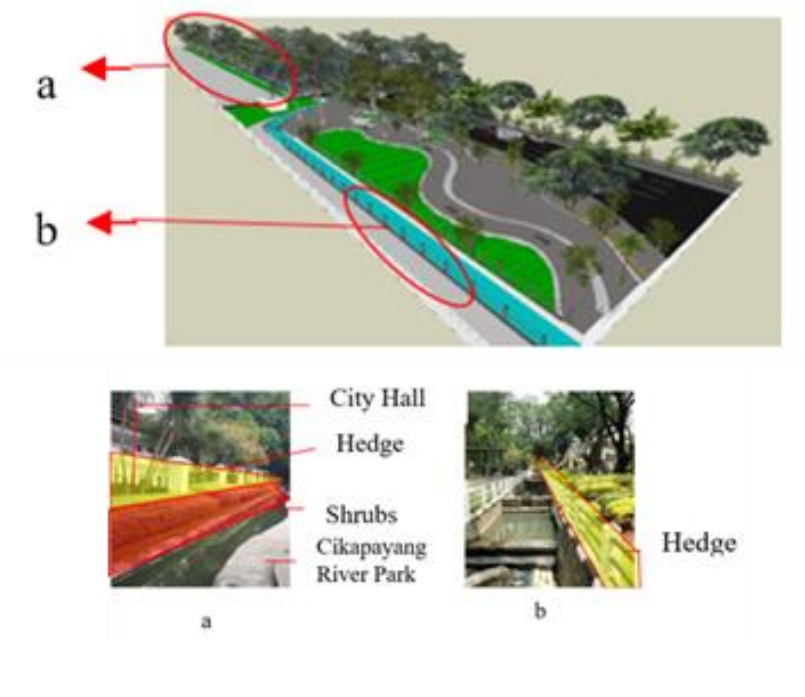

Figure 12: Barrier in Cikapayang River Park Source: (Author, 2020)

Cikapayang River is a particular object that dominates the Cikapayang River Park site. [9], park design and pedestrian design are made 
with steps and winding, as shown in Figure 13. The pattern in the Cikapayang River Park was made to suit the Cikapayang river, which became the central element of the Cikapayang River Park [9].
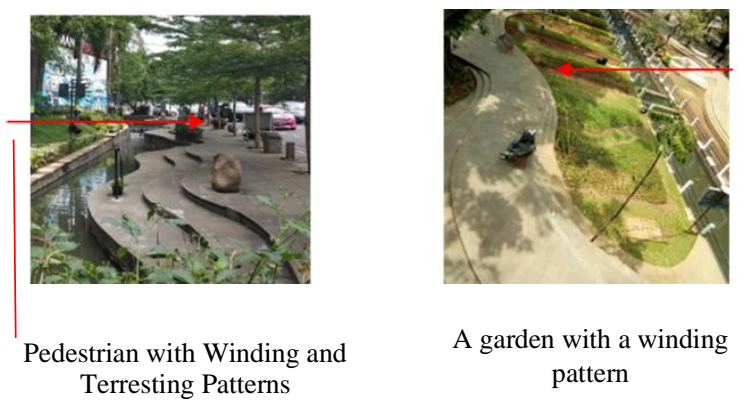

Figure 13: Pedestrian and Garden with Terrest and Winding Patterns Source: (Author, 2020)

\section{- User Circulation}

User Circulation consists of two circulations, vehicle circulation, and circulation of people. Circulation is the kinetics of movement and a study of the nature of movement [11].

\section{- Vehicles Circulation}

There is a motorized vehicle parking area at Cikapayang River Park, but it is not directly related to the park, as shown in figure 13. The parking area is located in the City Hall. This does not comply with the criteria [10] because no parking areas are provided that are directly related to Cikapayang River Park.

Cikapayang River Park does not provide a circulation area for motorized vehicles, and drop off zones to access the park, so vehicle users who will access the park, enter through the Bandung City Hall park. For public transportation such as city transportation, a bus stop is located opposite the Cikapayang River Park.

The bicycle parking area at Cikapayang River is directly related to the park; this parking area matches good accessibility [10]. The available bicycle parking area is inadequate, while bicycle users in Cikapayang River Park are numerous, so that bicycle users park their bikes in areas that are not their place.
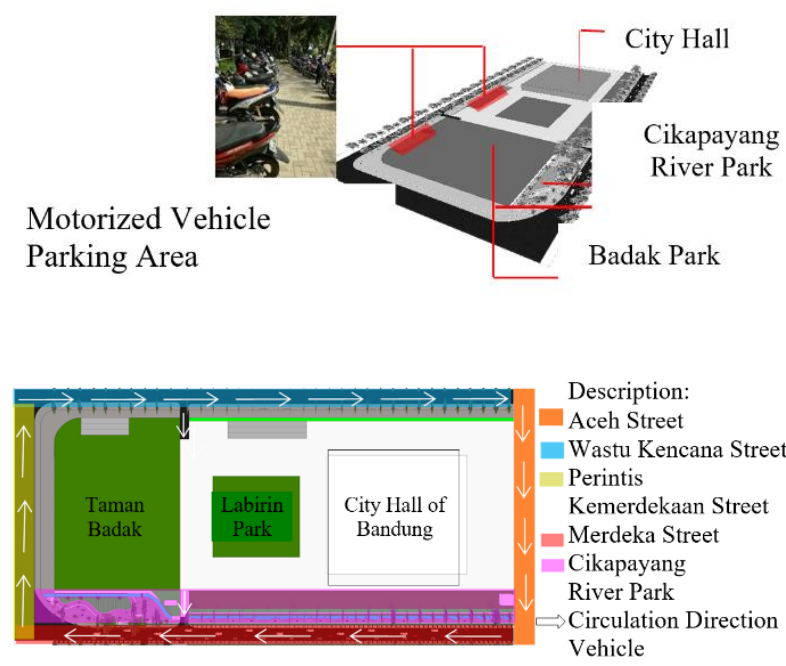

Source: (Author, 2020)

Figure 14: Motorized Vehicle Parking and Circulation Zones

\section{People Circulations}

In Cikapayang River Park, there are two types of steps, type 1 and type 2, shown in Figure 15, type 1 , which is located among pedestrians associated with Jalan Merdeka, and Cikapayang River Park. The stair edge has a champered type aiming to minimize accidents [10]; the shape of the stairs in this type does not have an open riser. In type 1 has $30 \mathrm{~cm}$ optrede, with a height of $30 \mathrm{~cm}$ optrede makes it difficult for users to climb stairs.

In type 2, Cikapayang Park is in the middle of the park, located between the plants and plazas in the park. The shape of the end of the stairs has a tapered shape, the shape of the end of the stairs must be curved to minimize accidents [10], the shape of the stairs in this type does not have an open riser. At Cikapayang River Park, optrade has $10 \mathrm{~cm}$ height, with $10 \mathrm{~cm}$ height, making it easy for users to climb stairs. 
The types of movements that exist in the Cikapayang River Park are horizontal, direct and linear movements, this movement depends on the elongated tread shape as in Figure 14, so that the circulation paths of the treads adjust to the linear tread shape.

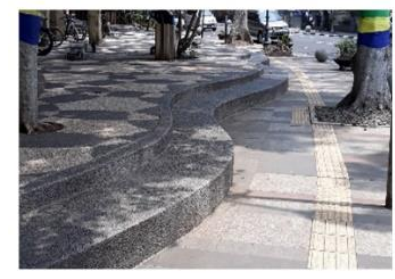

Type 1

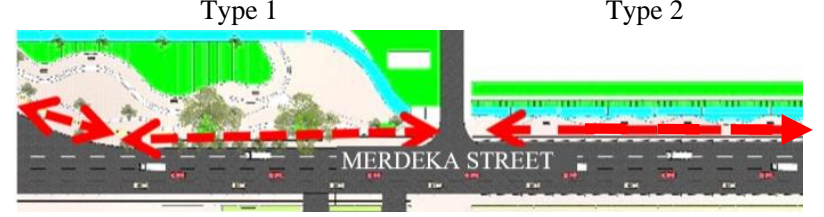

Description

$\longleftrightarrow$ Direction of People Circulation

Source: (Author, 2020)

Figure 15: Types of Steps and Linear Circulation Patterns at Cikapayang River Park

\subsection{Environmental Order of Site Components}

The Tread Component's environmental order is divided into two parts: the hardscape component and the softscape component. Softscape is a term used for material elements that come from nature. Hardscape components are artificial material elements or elements besides vegetation [11].

\subsubsection{Hardscape Components}

There are hardscape components in Cikapayang River Park, including street furniture, pedestrian, and signage shown in figure 16. Hard materials (hardscape) in the Cikapayang River Park have inorganic materials used in highly modified states and inorganic materials used in their natural state [11].

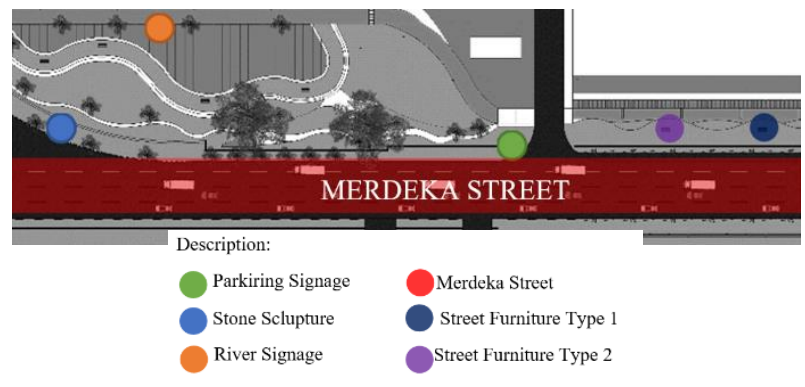

Source: (Author, 2020)

Figure 16: Hardscape Components in Cikapayang River Park

\subsubsection{Softscape Components}

There are softscape components found in Cikapayang River Park; there are trees and shrubs. Mahogany trees, banyan trees, palm trees, kiara payung trees, and ketapang kencana trees found in the Cikapayang River Park shown in Figure 17.

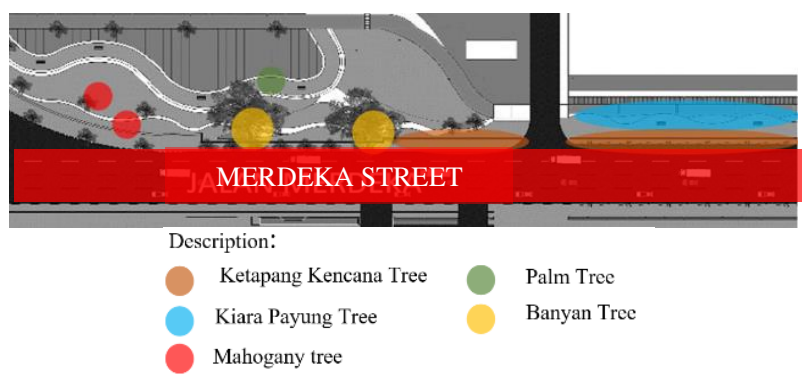

Source: (Author, 2020)

Figure 17: Softscape Components in Cikapayang River Park

Mahogany trees found in the park shed their leaves during the dry season. Then the banyan tree has a height of more than $10 \mathrm{~m}$ with a canopy width of 5-7 m; the palm trees are placed in the flower garden area. This banyan and palm tree does not shed its leaves in any season. Kiara payung trees are found in the pedestrian area that borders with City Hall. This tree has leaves that are shaped like a comb, with a tree height of about 8-10 m, with a trunk with a diameter of $10 \mathrm{~cm}$. These trees will shed their leaves when it is summer or dry. There are ketapang kencana trees along the pedestrian 
area which borders Merdeka street. Ketapang kencana trees in this park have a height of $7 \mathrm{~m}$ with a triangle-shaped canopy shape and do not shed its leaves in any season.

Banyan trees are classified as evergreen conifers [12], which are evergreen plants. Then based on characteristics such as plants that shed their leaves during the dry season, kiara payung and mahogany belong to the deciduous plant [12].

\subsection{Cikapayang River Water Purification}

Cikapayang River undergoes a purification process with circulation and water filters to produce clear water, but it is not suitable for drinking. One method in cleaning water is to install river stones to hold organic waste downstream of the river; then, the garbage is removed manually by the local sanitation staff periodically so that the river remains clean from rubbish. Some sponges are installed to contain domestic waste so that it does not pollute river water, as shown in Figure 20.

The river water purification method with a water filter process can be seen in Figures 18 and 19 using a reservoir. This process is the primary filter process [13] in the Cikapayang river water flow; this reservoir is located at the crossroads of the Aceh road and Jalan Merdeka, Bandung City precisely located in the Historical Park of the Bandung City.

So it can be concluded that this river water has two water purification systems, there are natural and chemical namely by naturally using river stone and sponge filters along the river water flow and chemical purification, by using chemicals as river water purifier namely by PAC (Poly Aluminum Chloride) in storage tanks.

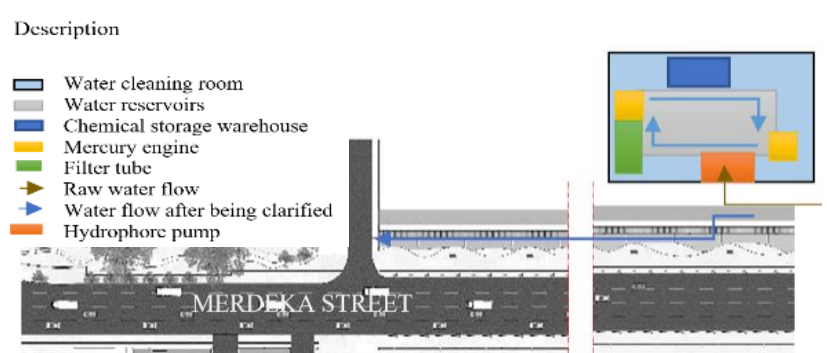

Source: (Author, 2020)

Figure 18: Keyplan of Cikapayang River Water Purification

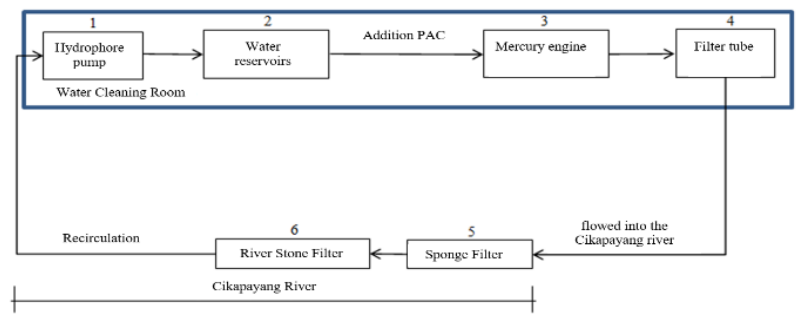

Source: (Author, 2020)

Figure 19: Cikapayang River Water Purification Process Scheme

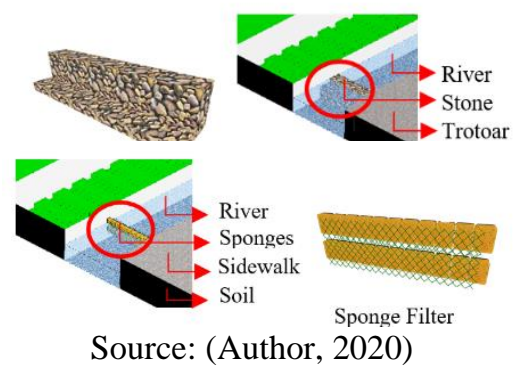

Figure 20: Natural Filter in the Form of gravel and a Mechanical Filter in the Form of a Sponge.

\section{Conclusion}

So it can be concluded from the results of on revitalizing environment order against the spatial outside in Cikapayang River Park area research, it can be concluded that:

- The positive impact of revitalization on changes in outside spatial planning in the Cikapayang River Park area is the creation of positive outer space, with the utilization of the outer space which was previously a less organized space into an outdoor space that can accommodate the activities of the 
community who visit the Cikapayang River Park

- There are two circulations to users in the Cikapayang River Park, namely the circulation of vehicles and people. Circulation of vehicles in the Cikapayang River Park includes parking areas for motorized vehicles. Still, they are not directly related to the park but are in the Bandung City Hall area. A bicycle parking area is provided at a place that is directly related to Cikapayang River Park. Circulation of people in the Cikapayang River Park, which has direct circulation with a linear path. The shape of this circulation is adjusted to the elongated tread shape

- In the Cikapayang River Park, there are hardscape and softscape materials. Hardscape material in the park has the type of inorganic materials used in highly modified state and inorganic materials used in their natural state, there are trees and shrubs as the softscape material found in this park, that can be used as shade trees, absorbent of air pollution, noise absorbers, and barrier of view

- The restoration of the Cikapayang River as a supporting component makes this open space alive and useful for the surrounding community. Restoration of the river in the Cikapayang River Park area is done by filtering water using natural filters in the form of stones and using filter sponges. In addition to using filters, manual cleaning is done by cleaning by Cikapayang River Park officers on a regular basis. Then purification is also done using a chemical clarification method using PAC (Poly Aluminum Chloride). This chemical purification is located in a special room which is located at the junction of Merdeka Street and Aceh Street by the storage method. In the room, there are utility tools for river water purification such as storage tanks, hydrophone pumps, mercury machines, filter tubes, PVC pipes and chemicals as a purifier

\section{Acknowledgement}

The benefits of changes in urban spatial planning in municipal buildings relating to revitalization before and after revitalization are the creation of positive outer space, creating useful green open spaces and accommodating community activities around Bandung City Hall.

The creation of a positive open space is one form of appreciation for the City of Bandung Spatial Planning that has revitalized the Merdeka Street's sidewalk area that borders the city hall into a useful park, as well as the benefits of the results of river water restoration which are beneficial to the city community in ecological terms and the environment.

\section{References}

[1] National Education Department, Language Center. Indonesian language dictionary. Jakarta; 2008

[2] Https://www.google.com/maps/ (edited), accessed 29 September 2018

[3] Kunto H. Wajah Bandoeng Tempo Doeloe. Bandung: PT. Granesia; 1984

[4] Government of Bandung, Bandung Spatial Planning Office (edited)

[5] Minister of Works Office, Regulations Minister of Works Office Number: 18/PRT/M/2010 about Area revitalization Guidelines. Jakarta: Minister of Works Office; 2010.

[6] Rubenstein HM. A guide to site planning and landscape construction. New York: John Wiley \& Sons, Inc; 1996.

[7] Ministry of Home Affairs, Ministry of Home Affairs Instruction Number 14 about Green open space arrangement in urban areas. Jakarta: Ministry of Home Affairs; 1988.

[8] Public Works Office, Number: 05/PRT/M/2008 About the guidelines for the provision and utilization of green open space in urban areas. Jakarta: Directorate of Public Works Department; 2008.

[9] Ching FDK. Architecture: Form space and order. Jakarta: PT Erlangga; 2007.

[10]Harris CW, Dines NT. Time saver standards for landscape architecture. New York: McGraw;1998..

[11] Hakim R, Hardi U. Landscape architecture designing components. Jakarta: Bumi Aksara; 2004

[12]Motloch JL. Introduction to landscape design. Canada: John Wiley \& Sons, Inc.; 2001. 
International Journal of Built Environment and Scientific Research p-issn: 2581-1347 | e-issn: 2580-2607 | Pg. 11 - 22

Volume 04 Number 01 | June 2020

[13]Sosrodarsono S, Tominaga M. River improvement and arrangements; Jakarta: PT. Pradnya Paramita;

[14]Asmadi K, Kasjono HS. Drinking water treatment 1985. technology. Yogyakarta: Gosyen; 2011 
(This page is intentionally left blank) 